they were not described in the report." Here he is right, but the scepticism, which was real as well as apparent, referred to the want of a description of the symptoms; and to the great majority of persons of ordinary education this, together with the whole tenor of the article, conveys the innuendo that there were no symptoms to describe or that they would not bear out the conclusion come to. Your correspondent admits "apparent scepticism" firstly as to the occurrence of henbane in the park. I beg to meet this and to answer the last sentence in the article of last week by saying that henbane does grow in the park. The second cause of "apparent scepticism " being founded on an errorwiz., that the deceased said she ate green sauce (she did not way this)-therefore falls to the ground.

I am, Sirs, your obedient servant,

Gorton, Manchester, Sept. 30th, 1895. B. W. MACARTHUR.

\section{THE INTERNATIONAL CONGRESS OF HYGIENE AND DEMOGRAPHY, BUDAPEST, 1894. \\ To the Editors of THE LANCET.}

SIRS,-I take the liberty of asking you kindly to grant space in your valuable paper for the following statements. We are now sending out to the members of the Congress the first volume of the Transactions of the Congress. Members who have not previously sent in their addresses, or who may have since changed their domicile, are respectfully requested to send in correct addresses so as to avoid delay in sending out the other volumes. Non-members of the Congress may obtain the Transactions by sending in a subscription of ten florins, Austrian money, together with two florins for postage; the amount to be sent in to the Director of the St. Rochus Hospital at Budapest. All other communications should be addressed to the editor as given below.

I am, Sirs, yours obediently,

Sigismuxd DE Gerloiry, M.D.,

Editor of the Transactions of the Congress.

St. Rochus Hospital, Budapest, September, 1895.

\section{"GUARDIANS AND MEDICAL OFFICERS." To the Editors of THE LANCET.}

SIRs,-As medical officer to, I believe, the largest and most populous district in the metropolis-the number of patients in my register reaching to about 2200 annually and having the attention of three relieving officers-I can speak with some experience regarding these officers and their ways. In the first place I must traverse your dictum that a relieving officer has no absolute discretion in dealing with an urgent case; probably he has no practical discretion in the actual working of the Act, as, according to the Consolidated Local Government Board Act, a medical officer might recommend this, that, or the other, but the relieving officer has absolute discretion to do just as he pleases. Of course, he takes all respon sibility, should he refuse to accede to the recommendation of a medical officer and death resulted. I consider this a great flaw in the Act, conferring great power and discretion on the relieving officer, who is least able to bear it. Our board sent out instructions some two years since that a medical officer in recommending relief should state not only what food was necessary, but the actual quantity of each foodstuff. This was found to be a complete dead letter. I found that the relieving officer gave out just what he had in stock, and, as regards quantity, he had to supply not only the patient, but the wants of the family, so that my quantities were of no avail. As regards stimulants, our board are very particular, and I can say, having been in office now about nine years, that no stimulant has ever been given as out-relief.

$$
\text { I am, Sirs, yours truly, }
$$

September 28th, $1895 . \quad$ DISTRICT MEDICAL OFFICER.

\section{"THE PHYSIOLOGY OF DEATH BY ELECTRIC SHOCK."}

To the Editors of THE LANCET.

SIRs,-I am unable to see what advantage or profit can be gained from the letters of Dr. Shettle under the above heading. Vague speculations as to the influence of the earth's magnetism upon the phenomena of life are unnecessary and tedious.
If Dr. Shettle has performed any experiments or collected any new facts respecting the physiology of death from electric shock, by all means let us have them, and let them be as briefly stated as possible. For my part I am entirely sceptical as to the production of electrical currents in the body by the flow of blood across the magnetic lines of force which traverse the body, and it does not even seem to me to be worth while discussing in detail many points raised by Dr. Shettle, where, in my opinion, either his premisses or his reasoning are unsound.

Sept.l29th, 1895.

I am, Sirs, yours obediently,

a PRACTICAL MAN.

Erratum.-In Dr. Alexander Morison's letter on nonstenotic mitral bruit in THE LANCET of Sept. 28th "valvular contraction" is printed instead of ventricular contraction.

\section{THE BATTLE OF THE CLUBS. (From oUR SPECIAL CoMmissioner.) (Continued from p. 815.)}

\section{Medicat aid Companies at Eastbourne.}

THE situation at Eastbourne differs fundamentally from what I have seen and described at Portsmouth. In the latter town a union of medical men has been formed to resist the encroachments of the friendly societies who seek to form lodges of children and females. At Eastbourne the question of the friendly societies has not yet been taken in hand, and for the moment the struggle is directed against the National Medical Aid Company, Limited. The method of action at Eastbourne is also totally different. For many years two assurance companies which deal mainly with the poor have done an extensive business in this town. The one is the Liverpool Victoria Legal Friendly Society and the other the Prudential Assurance Company. To secure life assurances the former of these companies became intimately associated with the National Medical Aid Company, Limited. It employs a considerable number of canvassers, and it would seem that these men find it easier to persuade people to insure against sickness than to insure their lives. The canvassers, therefore, very often open the negotiations by pointing out the advantage of paying 1d. per week to the National Medical Aid Company so as to secure the services of the medical men employed by that company. Then when this point has met with approval the canvasser explains that such medical insurance cannot be obtained unless the person in question also insures his life and that the life insurance is granted by the Liverpool Victoria Legal Friendly Society. This method of canvassing for life insurances proved so successful that the Prudential Assurance Company was compelled to adopt similar means. Thus the two great assurance companies which do the most business with the poorer classes of Eastbourne became, practically speaking, medical aid societies. This gave rise to serious grievances and abuses.

Early this year a private meeting was held. Some of the younger members of the profession, who suffered considerably from this state of affairs, approached the Eastbourne Medical Society. This is a purely scientific body constituted for social purposes, and not especially with a view to defend ing the material interests of the profession. Nevertheless, Dr. Muir Smith was allowed to read, last April, a paper to this medical society setting forth the abuses that had arisen. A resolution was carried to the effect that the medical profession should themselves organise a medical aid society, which would do the work that had previously been done in a manner contrary to the ethics of the profession and for the sole purpose of promoting the interests of commercial assurance companies. For this purpose the resolution carried at the meeting of the Eastbourne Medical Society urged that a charitable institution, an endowed provident dispensary which exists at Eastbourne, should be asked to take the matter in hand. The Provident Dispensary was requested to coopperate and reorganise on the lines approved by the general body of the profession at Eastbourne. These negotiations were not, howevcr, successful. It was stated that the fact that the dispensary in question had endowments made it difficult to alter its rules and methods of working. One of the great ohjects held in view was that 